\title{
National Transformation and Economic Resuscitation: Education the Way Forward
}

\author{
Dr. (MRS) Rabi Muhammad (MSTAN) \\ Department of Science and Vocational Education, Faculty of Education and Extension Services \\ Usmanu Danfodiyo University Sokoto, Nigeria
}

\begin{abstract}
This paper took an overview of educational development in Nigeria. The place of technical and vocational education in national transformation was discussed and the need for technical and vocational education for woman as a means of economic resuscitation.
\end{abstract}

Keywords: Education, National Transformation, Economic Resuscitation

\section{Introduction}

Education in Nigeria is a public activity and it is publicly regulated. It is provided as a necessary service. Systematic use of education to achieve security, prosperity and social well-being makes it a critical responsibility of the state craft. The state is responsible for financing education and it is responsible for stock taking and reckoning and setting national priorities. It is responsible for periodic review and change in the system with the view to improving the efficiency of operational procedures and devising, alternative processes and models that will transform the system.

According to Fafunwa (1974:123) "there has been over production of those who could write and talk and under supply of those who could till and repair". It is perhaps in line with this realization that the present administration came up with its transformation agenda which draws its inspiration from the vision 20:2020 and the first national implementation plan (NIP) with special emphasis on Technical and Vocational Education (TVE) considering its crucial role in the production of appropriate numbers of skilled persons essential for national self-reliance and rapid economic development.

This paper took an overview of educational development in Nigeria. The place of technical and vocational education in national transformation was discussed and the need for technical and vocational education for woman as a means of economic resuscitation.

\section{Educational Development in Nigeria: An Overview}

Every society has a way of educating its children to suit its developmental needs. Nigeria is not an exception. Nigeria has its own traditional system of education long before the coming of the British Colonizers. The system of education then, was relevant and articulated well with the cultural elements of the society. The aims were relevant to the needs and social realities of the people. They were centered on preparation for cultural heritage and the survival of the individual in the society.
The arrival of the missionaries in Nigeria changed the effectiveness of indigenous education. The first formal school was opened in 1842 almost immediately the first English speaking missionaries arrived in Nigeria and this formed the nucleus of what we referred to as the formal educational system (Salawu, 2006) up to 1872 the colonialists left education in the hands of the missionaries and only later did government either support or supplement mission effort. The missionaries from the very beginning stressed the role of education in their work. That is, simply to teach the people how to read and interpret the Bible.

The education system during the colonial period was colonial in nature. It was good for the country and society for which it was planned, that is, it was good for Britain and the British Society (Ogunsaju, 1983). However, it was not relevant to the Nigerian society as it neglected the country's cultural and social background. It also failed to produce educated graduates who could help the country in laying the foundation for economic freedom by producing the manual skills and expertise necessary for successful industrial, technological and agricultural development of the nation.

The post-colonial era witnessed a new consciousness in educational development in Nigeria. After independence there was the need to forge ahead in the country's educational development at its various levels to enhance human capital which was urgently needed for possible industrialization. The need therefore for self-efforts in order to plan, design, strategize and implement towards scientific and technological advancement of the society and for the good of the individuals. The growth and development in education in post independent Nigeria utilized as point of reference the recommendations of the Ashby commission which was set up in April 1959. (Ajuzie, 2001.) The Commission's terms of reference were to survey higher education requirements for the next 20 years (1960-1980.) Ashby recommended for various levels of education; primary, secondary, technical education and the higher institutions as follows:

a) Primary schools: there should be increase in the scope of primary education of the citizens.

b) Secondary education should also increase in capacity of admission.

c) Need for establishment of national high schools by the Federal Government. 


\section{International Journal of Science and Research (IJSR) \\ ISSN (Online): 2319-7064}

Index Copernicus Value (2016): 79.57 | Impact Factor (2015): 6.391

The Ashby report became the basis of educational development for manpower in the 1960s and its effect was the rapid expansion in primary education, diversification of secondary school curriculum, new efforts in improving technical and agricultural education and widespread expansion in university education (Ajuzie, 2001).

A national curriculum conference was held in 1969 to interpret these recommendations into workable actions. The conference was sponsored by the Nigerian educational research council in Lagos. It was to provide a forum for the discussion of an appropriate curriculum for the nation's schools. The four-day national conference set the pace for two successive national curriculum workshops in 1971 and 1974. The 1971 workshop produced guidelines on primary school curriculum while the 1974 workshop produced guidelines on secondary school curriculum.

Eventually, a national policy on education was produced in 1977. This was the first time Nigerians made efforts at identifying, integrating and translating national concerns. The national policy on education gave birth to the 6-3-3-4 system of education.

The policy highlighted the urgency of seriously embarking on the production of technical skills as fundamental step towards technological development and industrialization. Thus the emphasis on the training of scientists, engineers, doctors, technicians and allied vocational and professional manpower in the age of science and technology.

The 6-3-3-4 system means that a child is to spend 6 years in the primary school, secondary school level should be of sixyear duration and be given in two stages, a junior secondary school and senior secondary school each stage being of three-year duration and four years of post-secondary education. The JSS is prevocational and academic in which students will learn basic subjects and also acquire skills. Equal prominence is given to vocational subject such as carpentry, metal work, technical drawing and English, social studies mathematics and science. If a student stops at this level, he/she may go into apprenticeship to a programme of out of school vocational training. For those who go beyond the junior secondary school level there are various areas of specialization such as agricultural, technological, basic science, commerce, teacher education, arts and crafts etc.

\section{The State of Education in Nigeria Today}

The major emphasis in the planning and development of education in Nigeria from independence to date has been with reference to the production and supply of men and women of quality. Those that possess the knowledge and skills necessary for carrying out the works that could raise Nigeria from being one of less developed countries into one capable of taking a full part in world affairs as an equal with other nations.

An awareness of what education seems to be today can effectively help in shaping the future. The harsh reality of the situation of education in Nigeria today is that the system is in shambles. The general comment is that standard has fallen and there is a crisis in the system. According to Salawu (2006) there is a decay in the whole system within the last few decades. Dantsoho earlier (2003:136) also lamented that "the standard of education is falling at an alarming rate". The general decline in the quality of education in the country could be seen clearly when we assess the generality of the students at all levels of the systems in the following areas:

- Literacy

- Language skills and

- Logical reasoning

This trend could be attributed to the following circumstances:

- Poor funding

- General decay of the infrastructure

- Serious shortage of qualified and competent teachers

- Overcrowded classrooms

- Gender disparity

- Lack of transparency in the management of the system.

- Poor performance of candidates in national examinations such as NECO, WAEC, NABTEB etc.

- Examination malpractice

- Cultism

- Lack of effective monitoring of the system.

\section{Technical and Vocational Education (TVE)}

Technical and Vocational Education (TVE) is an aspect of general education that is concerned with improving the quality of life of the individual and the society. According to Yakubu (2006) it is an integral part of general education, a means of preparing for occupational fields and effective participation in the world of work; an aspect of life-long learning and a preparation for responsible citizenship; an instrument for promoting environmentally sound sustainable development and a method of facilitating poverty eradication.

Quality Technical and Vocational Education and Training (TVET) would help develop the individual's knowledge of science and technology in broad occupational area requiring technical and professional competence and specific occupational skills. It develops the knowledge and skills that will help the workforce become more flexible and responsive to the needs of the local markets while competing in the global economy.

The industrialized nations of the world attained their present position by according great importance to investment in human capital in the area of science and technology. This is because in today's world science is the pivot on which development challenges hinge. According to a World Bank report (1991:25) to successfully confront challenges of development, a developing nation must undertake three major tasks. These are -

- Acquire and adapt global knowledge and create knowledge locally

- Invest in human capital to increase the ability to absorb and use knowledge.

- Invest in technologies to facilitate both acquisition and absorption of knowledge.

It is pertinent to remark that a viable economic base is difficult to attain without a sound and well-articulated

\section{Volume 6 Issue 12, December 2017}




\section{International Journal of Science and Research (IJSR) \\ ISSN (Online): 2319-7064}

Index Copernicus Value (2016): 79.57 | Impact Factor (2015): 6.391

science and technology education. Nigeria is endowed with huge natural and human resources, the process of translating these into gainful economic activities requires huge investment in science and technology education.

Since independence, successive Nigerian governments have placed a lot of priority in developing the nation through science and technology education. The Nigerian National Policy on Education (2004) categorically stated the objectives of education in Nigeria thus: -

"Nigerian education should be geared towards functional education, national unity and integration, self-realization, better human relationships, self and national economic efficiency, effective citizenship, political progress, national reconstruction, scientific and technological progress". P-10

This shows that functionality is a key word in the philosophy of Nigerian Education. Emphasis has been on education for utility, for the development of the individual for the growth and stability of the state.

The need for technical advancement for the purpose of industrialization started in the late $70 \mathrm{~s}$. This resulted in the setting up of science schools and later Universities of Technology and polytechnics. These were all deliberate efforts towards achieving technological advancement in the country. Towards the end of the 70 s and early 80 s the desire to acquire technical and vocational education began to wane and the preference for academic was on the increase. According to Aina (2006), today, it is common knowledge and great concern that technical and vocational education in the country is in a comatose state. The Education Trust Fund (2006) organized a national workshop on "Revamping Technical Education to face the challenges of Technological Development in Nigeria". The following observations were made in a communiqué issued after the workshop:

1) Diversity of conceptual definitions of terminologies being used in Technical Education which impede understanding of what TVE is all about.

2) Inadequacy of delivery system due to lack of teachers, obsolete equipment and out dated curriculum.

3) Inadequacy of Resource input in terms of funding, facilities, equipment provision, tutorial personnel etc.

4) Poor management of resource input in the sector and selective approach that hitherto has been adopted in solving the problems associated with resource input.

5) Policy constraints of access to TVE development

6) Inadequate economic reward system for those who have chosen TVE professions or fields.

7) Low esteem of products of TVE arising from societal misconception of the relevance of TVE to national development.

8) Low level of private sector participation in TVE particularly in SIWES/Industrial Attachment and curriculum development. (The house journal of ETF) 1213 .

However, serious efforts must be made towards proper implementation of the agenda otherwise its good intentions like previous efforts will fail. Political will is the main obstacle to significant reforms in the country's education system. It is high time that we do away with the rhetoric and concentrate on concrete issues. Government should demonstrate more commitment and match words with timely action. Let all energies and efforts be aimed at taking the country to new heights through production of sound and useful knowledge and productive skills for growth and development (Majasin, 1998).

\section{Technical and Vocational Education for Women as a tool for economic Resuscitation}

A key to the development of the individual and the society is the acquisition of technological capabilities for all citizens. At whatever level primary, secondary or tertiary, science is concern with making the individual young or old, male or female, scientifically literate with the view to making him/her have a better survival. For the society the level of scientific and technological advancement determines the level of development. That is, it is an index of social, political and economic development of the nation.

The Nigerian National Policy on education emphasized that there should be no sex barriers in the type of education that should be provided for all Nigerian children. That is, all Nigerian children should be exposed to the type of education that would prepare them for useful living within the society. At primary school level all children study the same subjects, so girls access to any form of education is dependent on their rate of enrolment. But at the secondary school level fewer girls than boys opt for the science and technology related subjects. As a result of this few girls are found in the science and technology related facilities at the tertiary level (Adebola, 2003).

The major reason for this state of affairs is sex segregation in education and society, caused by gender stereotyping and other inappropriate factors. The attitude of parents, teachers and even female students towards the sciences is detrimental to the scientific and technological aspirations of the nation. To some parent's girls who succeed in "male careers" such as engineering, technology, architecture etc are somewhat abnormal and poor prospects for marriage. To them girls should be submissive, non-participatory and non-assertive. They should be best trained for taking care of the home.

Thus there is a low involvement of females in technical and vocational education as females are usually discouraged from pursuing technical education due to its high scientific and mathematical involvements, its practical nature as well as the high risk involved in working with machines. Yalam and Aliyu (2000) in a study conducted in Bauchi state discovered that, the masculine nature, mathematical involvement and the risk of working with machines in technical education tend to discourage females from pursuing technical education.

Since independence in 1960, Nigeria has adopted a number of policy measures to bring about rapid and balanced growth in the various sectors of the economy. Prior to 1970s, the mainstay of the country's economy was agriculture. Over the years per capital food production stagnated while the overall share of the agricultural sector in Gross Domestic Product (GDP) dropped geometrically. Then the period of oil boom which was followed with rapid changes. Politics with attendant uncertainties continues to affect all aspects of

\section{Volume 6 Issue 12, December 2017}




\section{International Journal of Science and Research (IJSR) \\ ISSN (Online): 2319-7064}

Index Copernicus Value (2016): 79.57 | Impact Factor (2015): 6.391

life in the country. Evidence of recession in the economy became clearly visible. People suffer inadequate access to resources such as education, basic health services, infrastructure and opportunity for a better life. The general opinion is that the economy is functioning badly. The economy had lost the impetus for growth, private participation is extremely low, unemployment is high, balance of payment reserves had been depleted there is maldistribution and mismanagement of resources.

\section{Causes of Economic Recession in Nigeria}

- Over dependence on petroleum as a source of income

- High rate of importation

- Resource management

- High rate of unemployment

- Lack of diversification of the country's economy

- Lack of adequate manpower development

- Lack of quality education

- Corruption

- Insecurity etc.

Having recognized that the Nigerian economy is at present facing serious problem, it is only natural that we should be looking for effective ways of turning the situation round. It is in this light that we are recommending technical and vocational education for women. According to Oloyele (2011), the potential human knowledge is said to reside in female heads and to make these potential ideas into real ideas requires equal education and rights for women especially in the area of science technology, engineering and mathematics (STEM). Also Mahmud (2007) quoted the farmer secretary general of the United Nations Kofi Annan saying that there is no tool for development more effective than the education of girls and women. That no policy is likely to raise economic productivity, lower infant and maternal mortality, improve nutrition, promote health including the prevention of HIV/AID and increase chances to education for the future generation than education for girls and women. "Let us invest in women and girls".

During the United Nations decade for women in 1975, it was realized that women contributed $50 \%$ of the world's population. Unfortunately, however they are only $1 \%$ of the world's wealth (Ibrahim and Paiko, 2003). Thus only 50\% of Nigeria's human resource is contributing to its development process. This is why there is a slow rate in the overall development of the nation. To speed up the industrial growth in terms of inventions, maintenance and use of machines women should be involved actively in technical and vocational education.

Umar and Aliyu (2008) identified the following as areas in which technical and vocational education can enable its recipient be better, more useful and productive citizen of the nation as it -

- Stimulates productivity

- Increase employability

- Increase learning capacity

- Reduce dropout rate

- Stimulates technological and industrial development

- Improve nutrition of the citizenry
- Produce independent hands

- Increase entrepreneurship

Aina (2006) summarized the benefits of technical and vocational education thus-

"A prudent and well-bred craftsman/woman or technician will make the difference in the success or otherwise of a production process, the availability and affordability of food all year round, efficient transportation and housing systems, the supply of essential utilities and in general, the quality of life available to the citizenry". 18

For the economy of the nation to be resuscitated gender equity must be achieved in and through education. This could be done by allowing individuals males/females acquire the most valued characteristics and skills in the society. There must be skilled personnel (males and females) who are enterprising and self-reliant and who are equal to the task of rapid economic, social and political development of the nation.

For positive and meaningful transformation of the economy therefore acquisition of relevant and appropriate technology for all citizens (males and females) is necessary. This is because it enhances employment, it improves the quality of life of all citizens, it reduces poverty, limiting the incidence of social vices due to idle-living and promotes a culture of peace, freedom and democracy (UNESCO, 1999).

\section{References}

[1] Adebola, I. S (2003) Girls Participation and Performance in Secondary School Further Mathematics in Ijebu-ode, Ogun State, Nigeria. Standard for Science, Technology and Mathematics Education Research, Lagos, Nigeria. Victory Printers Nigeria, Limited.

[2] Aina, O. (2006): Technical and Vocational Education: The Way Forward. The House Journal of Education Trust Fund (ETF) Vol.2, No. $32^{\text {nd }}$ Quarter Edition.

[3] Ajuzie, M.V. (2001): A Concise History of Education in Nigeria: Issues and New Challenges. I-Cell Press, Akoko, Lagos.

[4] Dantsoho, B. A. (2003): Management of Educational Resources and its Relationship to the falling standard of education in Nigeria School System. Journal of Educational Planning and Management. 1(1) 205-212.

[5] Fafunwa, A.B. (1974): History of Education in Nigeria. London - Geoge Allen \& Unwin Ltd.

[6] Federal Republic of Nigeria (2004): National Policy on Education $4^{\text {th }}$ (ed) Lagos NERDC press.

[7] Ibrahim I. \&Paiko Y.B. (2003): Gender Issues and Technology Education in Nigeria Standards for Science Technology and Mathematics for Science Technology and Mathematics Educational Research Lagos (Nigeria) Victor Printers Limited.

[8] Lewis L.J. (1976): Society, School and Progress in Nigeria Pergamon Press London.

[9] Mahmud, H.U. (2007): The effect of Negative Parental Attitude Towards Women Education in Nigeria with Particular reference to Northern Nigeria. Journal of Educational Resource, and Development 1(1). 


\section{International Journal of Science and Research (IJSR) \\ ISSN (Online): 2319-7064}

Index Copernicus Value (2016): 79.57 | Impact Factor (2015): 6.391

[10] Majasin J.A. (1998): Qualitative Education and Development Spectrum Books Limited, Ibadan, Nigeria.

[11] Obanya, P.A.I. (2004): The Dilemma of Education in Africa. Ibadan Heinemann Educational Books (Nigeria) Plc.

[12] Ogunsajo S. (1983): Educational Planning Progress in Nigeria. An Historical Perspective. Nigerian Education: Trends and Issues. Adesina, Akinyemi and Ajayied University of Ife Press Limited Ile-Ife, Nigeria.

[13] Oloyede, O.I. (2011): Gender Based Imbalance on Women's Right Issues and Reforms in Science Technology Engineering and Mathematics (STEM) Education in Nigeria. Proceedings of the Annual National Conference of the Science Teachers Association of Nigeria (STAN) Abonyi (ed) HEBN Publishers Plc.

[14] Salawu, A.A. (2006): The Challenges in Nigerian Education in the $21^{\text {st }}$ Century. A lead paper presented at the Annual National Conference Organized by Shehu Shagari College of Education Sokoto. $26^{\text {th }}-30^{\text {th }}$ June.

[15] Taiwo, C.O. (1983): The Nigerian Educational System; Aims, Plans and Implementation. Nigerian Education Trends and Issues. Adesina, Akinyemi\&Ajayi (ed). University of Ife Press Limited Ile-Ife, Nigeria.

[16] The House Journal of ETF, (2006). Vol. 2(3) 12-13.

[17]Umar, M.S. \&Aliyu L.S. (2008) Relevance of Vocational and Technical Education to Vision 2020. A paper presented at the Annual Conference on Nigeria's Vision 2020 and Relevance of Education Sector. Organized by Shehu Shagari College of Education, Sokoto. $28^{\text {th }}-31^{\text {st }}$ July.

[18] UNESCO (1999): United Nations Educational Scientific and Cultural Organization (UNESCO) publications for the international literacy year.

[19] World Bank Report (1999): Higher Education: The Lesson of Experience. Washington D.C. - The World Bank.

[20] Yakubu, N.A (2006): New Approaches to Technical and Vocational Education (TVE). The House Journal of Educational Trust Fund (ETF). Vol. 2, No. $32^{\text {nd }}$ Quarter Edition.

[21] Yalam, S. A. \&Aliyu M.B. (2000): Low Involvement of Female in the Development of Technical Education in Nigeria. Challenges and solutions. Improving Teacher Education in $21^{\text {st }}$ Century Nigeria Challenges and Strategies. Publication of Department of Arts and Social Science Education in Association with the Faculty of Education. University of Jos, Jos, Nigeria. 